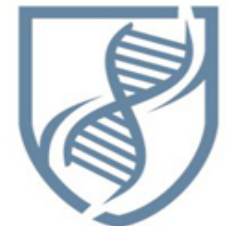

Journal of Bioscience and Applied Research

\section{JBAAR}

WWW.JBAAR.ORG

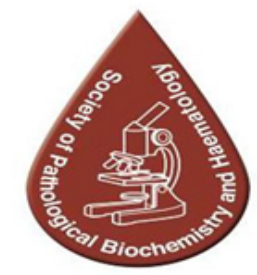

\title{
Effectiveness of nano composite and ceramic in treatment of drinking water
}

\author{
Mohamed T. Shaaban ${ }^{1}$, Mahmoud M. Hazaa ${ }^{2}$, Alshaimaa A. Aglan ${ }^{3}$ \\ 1,3- Botany Department, Faculty of Science, Menoufia University, Egypt. \\ 2- Botany Department, Faculty of Science, Benha University, Egypt. \\ (Corresponding author e.mail.shoshit_2@yahoo.com)
}

\begin{abstract}
Ground water contains some dissolved heavy metals and other elements which are so dangerous matter that all must face and find solutions for it. This study aims to use safe methods for water treatment using nano composite and ceramic particles.TDS (Total Dissolved Salts) with nano composite decreased from (740 to 654) $\mathrm{mg} / \mathrm{L}$ while with ceramic it decreased from (740 to 538$) \mathrm{mg} / \mathrm{L}$. Conductivity decreased from (1195 to 1080) $\mu \mathrm{S} / \mathrm{cm}$ in presence of nano composite while with ceramic it was reduced from (1195 to 893) $\mu \mathrm{S} / \mathrm{cm}$. Fe with nano composite reduced from $(0.41$ to 0.23$) \mathrm{mg} / \mathrm{L}$ while with ceramic it reduced from $(0.41$ to $0.11) \mathrm{mg} / \mathrm{L}$ and $\mathrm{Mn}$ decreased from (1.2 to 0.6$) \mathrm{mg} / \mathrm{L}$ with nano composite while with ceramic it decreased from (1.2 to 0.12$) \mathrm{mg} / \mathrm{L}$. Total hardness with nano composite decreased from (400 to 330) $\mathrm{mg} / \mathrm{L}$ while with ceramic it decreased from (400 to 250) $\mathrm{mg} / \mathrm{L}$. Sulfate increased from (82 to 104 ) $\mathrm{mg} / \mathrm{L}$ with nano composite while with ceramic it increased from (82 to 120$) \mathrm{mg} / \mathrm{L}$. Phosphate reduced from $(0.45$ to 0.34$) \mathrm{mg} / \mathrm{L}$ with nano composite while with ceramic it reduced from $(0.45$ to 0.15$) \mathrm{mg} / \mathrm{L}$. Ammonia with nano composite decreased from (0.8 to 0.5$) \mathrm{mg} / \mathrm{L}$ while with ceramic it decreased from $(0.8$ to 0.55$) \mathrm{mg} / \mathrm{L}$. Ground water is contaminated with pathogenic bacteria and coliforms. The bacteriological results showed that all the treated sample had no pathogenic bacteria (Vibrio cholera, Klebsiella pneumonia, Aeromonas sobria, Aeromonas hydrophila, Aeromonas caviae).
\end{abstract}

Keywords: Ground water contamination, Water treatment, Nanocomposite

\section{Introduction}

Water is essential to sustain life, and availability of safe drinking water is very important. Ground water and surface water are the two main sources of drinking water in Egypt.
Owing to the rapid growth of the population and increasing consumption of water, Egypt depends on groundwater in drinking water plants, although it has the great Nile River (El Tahlawi et al. 2008). Quality of groundwater is equally important to its quantity owing to the suitability of water for various purposes. Water quality analysis is an important issue in groundwater studies. Variation of groundwater quality in an area is a function of physical and chemical parameters that are greatly influenced by geological formations and anthropogenic activities (Subramani et al. 2005). Drinking water should be clear and free from objectionable tastes, odors, harmful chemicals and microorganisms of these desired sanitary qualities. Every effort should be made to achieve drinking water quality as high as practicable, otherwise people life are extremely subjected to hazardous effects. Proper selection and protection of water sources to be used for supplying water treatment systems are of prime importance in the provision of safe drinking water.

Biofilms have been successfully used in water treatment for over a century (Atkinson, 1975). It was not until the early 1980s, however, that the advantages of this type of bioprocess became a focus of interest for a considerable number of researchers, not only in the field of water and wastewater treatment, but also in many other areas of biotechnology (Adler, 1987). A large number of research projects are currently being conducted on biofilm reactors for the production of bioactive substances, for drinking water and wastewater treatment (Lazarova and Manem, 1995). Microbial biomass is used to degrade contaminants, nutrients and organics in wastewater recent developments may mean that biological drinking water treatment may become more feasible and more likely to be accepted by the public (Abdel-Dayem, 1994). Bacteria gain energy and reproduce by mediating the transfer of electrons from reduced compounds (compounds that readily donate electrons) to oxidized compounds (compounds that readily 
accept electrons). Once electrons are donated by a reduced compound, they travel back and forth across a cell's mitochondrial membrane in a series of internal oxidationreduction reactions. Ultimately, the electrons are donated to the terminal electron-accepting compound (Madigan et al., 1997). The aim of this work is the groundwater treatment by using nano composite ( nano polymer) and ceramic accompanied with bacterial biofilm in Shebin EL-kom city Menoufia Government, Egypt.

\section{Materials and Methods}

\section{2 .1 .Sampling procedure:}

Samples from ground water well in Shebin El-Kom city belong to Menoufia Government were collected monthly from April to December 2014. Sampling was carried out according to Standard Methods for Examination of Water and Wastewater $20^{\text {th }}$ edition. Sodium thiosulphate was added to chlorinated samples to a final concentration of $0.1 \%$ to neutralize the residual chlorine and prevents contamination of bactericidal action during transit (Public health laboratory service water sub-committee 1953) (Shipe and Fields, 1956). Samples were preserved immediately after collection by acidifying with concentrated nitric acid to $\mathrm{pH}$ less than 2 by adding $5 \mathrm{ml}$ nitric acid to 1 liter water samples and put in refrigerator (Batley and Gardner, 1977 and Subramanian et al., 1978.).

\section{2 .2 .Bio treatment of trace metals:}

Two liters of ground water have been treated by two methods. The first, by adding $40 \mathrm{gm}$ of non toxic nano polymer composite granules that have been prepared by physics dept.; Fac. Sci. Benha Univ. and the second by adding $200 \mathrm{gm}$ of milled ceramic after autoclaved at $121^{\circ} \mathrm{C}$ for 20 minutes. Both of nano composite and ceramic act as a substrate for biofilm formation. The both mixture were aerated for 24 hrs. These samples of treated water have been uptake for determining the concentration of cations and microbiological analysis (Hazaa et al., 2015).

\section{2 .3 . Physicochemical parameters:}

Physicochemical parameters were measured using the method described by standard methods for examination of water and wastewater $20^{\text {th }}$ edition. Temperature was measured using a manual thermometer $\left(110^{\circ} \mathrm{C}\right)$ graduated to $0.1{ }^{\circ} \mathrm{C}$.Turbidity was measured directly by using a digital turbidity meter (WTW Turb550) . Conductivity and TDS were measured directly by using a digital meter (WTW Inolab 720) (Rossum, 1975). PH was measured directly by using a digital pH meter (WTW PH 3110). Total and calcium hardness by EDTA titrimetric method (Betz and Noll, 1950., Goetz and Smith, 1959., Schwarzenbach and Flaschka, 1969). Alkalinity was determined by titration method against $0.2 \quad \mathrm{~N} \mathrm{H}_{2} \mathrm{SO}_{4}$ (ASTM. Standard Methods $20^{\text {th }}$ ). Chlorides were measured by titration method against $\mathrm{AgNO}_{3}$ ( Paustian, 1987). Iron ions were measured by phenanthroline method (Mehlig and Hulett, 1942., Caldwell and Adams, 1946). Manganese ions were measured by the persulfate method(Nydahl, 1949). Ammonia were measured by nessler method(Std method $19^{\text {th }}$ edition). Nitrate were measured by UV spectrophotometric screening method (Armstrong, 1963). phosphate were measured by stannous chloride method (Sletten, 1961). sulfate were measured by the turbidimetric method (Rossum and Villarrus, 1961). Free chlorine was measured by DPD (N,N-diethyl-p-phenyl enediamine) colorimetric method (Palin, 1957). All of spectrophotometric measurements were performed by spectrophotometer (cecil CE7400).

\section{2 .4 .Isolation of bacteria :}

Detection and enumeration of total coliform using m-Endo LES agar medium (Difco) (Dutka, 1981and Evans et al., 1981), Fecal Coliform using m-FC agar (Difco) (Green et al., 1980 and Sartory, 1980) and fecal streptococcus using m-enterococcus agar (Merck) (Gross, et al. 1975 and Facklam and Carey, 1985) were determined by membrane filter (MF) technique (APHA, 1998) (Sartorius SM 16828) which depends on sample filtration through a 47-mm, $0.45 \mu \mathrm{m}$ pore size cellulose membrane filters that retain the bacteria present in the sample. The filters were put onto the medium, using a rolling action to avoid trapping air bubbles between the membrane filter and the underlying medium. The plates were inverted and incubated at $35 \pm 0.5{ }^{\circ} \mathrm{C}$ for $24 \mathrm{~h}$ in incubator, incubated at $44.5 \pm 0.2{ }^{\circ} \mathrm{C}$ for $24 \mathrm{~h}$ in water bath and incubated at $35 \pm 0.5{ }^{\circ} \mathrm{C}$ for $48 \mathrm{~h}$ in incubator respectively. Detection and enumeration of heterotrophic bacteria by heterotrophic plate count test (HPC) by pour plate method using R2A agar media (MERCK). the plates were inverted and incubated at $35 \pm$ $0.5{ }^{\circ} \mathrm{C}$ for 48h( Klein and WU., 1974 , Bell et al., 1980 and Means et al.,1981)

\section{2 .5 .Identification of bacterial isolates :}

Bacterial isolates were purified and identified at Reference Laboratory for Drinking Water (Shobra El Khema Laboratory of Holding Company of water and waste water). Biochemical tests using VITEK 2 kits for identification of bacterial isolates.

\section{Results}

\section{3 .1. Physicochemical assessment of water sample 3.1.1.Temperature $\left({ }^{\circ} \mathrm{C}\right)$ :}

The range of temperature of Shebin El-Kom well during sample collection in 2014 ranged from 18 to $28^{\circ} \mathrm{C}$ the highest value in August and the lowest in December.

\subsubsection{Turbidity Nephelometric turbidity unit (NTU) :}

Values during the period of samples collection ranged between 0.84 and 1.8 (NTU) the highest value was recorded in December and the lowest was in July.

\subsubsection{Water (pH) :}

Values ranged between 7.6 and 8.0 the highest value was measured in December and the lowest was in July.

\subsubsection{Total dissolved solids (TDS) :}

Values ranged between 703 and $737 \mathrm{mg} / \mathrm{L}$ the highest value was recorded in December and the lowest was in June. 


\subsubsection{Conductivity $(\mu \mathrm{S} / \mathrm{cm})$ :}

Value ranged between 1118 and $1175 \mu \mathrm{S} / \mathrm{cm}$ the highest value was recorded in December and the lowest was in June.

\subsubsection{Total hardness (mg / L) :}

Values ranged between 400 and $450 \mathrm{mg} / \mathrm{L}$ the highest value was measured in December and the lowest was in June.

\subsubsection{Calcium hardness ( $\mathrm{mg} / \mathrm{L})$ :}

Values ranged between 240 and $290 \mathrm{mg} / \mathrm{L}$ the highest value was measured in May and the lowest was in November.

\subsubsection{Magnesium hardness (mg/L) :}

Values ranged between 130 and $180 \mathrm{mg} / \mathrm{L}$ the highest value was recorded in May, September and the lowest was in October and November.

\subsubsection{Total alkalinityCaCO3(mg/L):}

Values ranged between 380 and $430 \mathrm{mg} / \mathrm{L}$ the highest value was measured in July and the lowest was in September and October.

\subsubsection{Chlorides $(\mathrm{mg} / \mathrm{L})$ :}

Values ranged between 85 and $120 \mathrm{mg} / \mathrm{L}$ the highest value was recorded in December and the lowest was in April.

\subsubsection{Iron(mg/L) :}

Values ranged between 0.26 and $0.4 \mathrm{mg} / \mathrm{L}$ the highest value was recorded in August and September and the lowest was in April.

\subsubsection{Manganese $(\mathrm{mg} / \mathrm{L})$ :}

Values ranged between 1.0 and $1.4 \mathrm{mg} / \mathrm{L}$ the highest value was recorded in May and the lowest was in April and December.

\subsubsection{Sulfate (mg/L):}

Values ranged between 50 and $144 \mathrm{mg} / \mathrm{L}$ the highest value was measured in July and the lowest was in May.

\subsubsection{Phosphate (mg/L):}

Values ranged between 0.37 and $0.7 \mathrm{mg} / \mathrm{L}$ the highest value was recorded in November and the lowest was in April.

\subsubsection{Nitrate (mg/L):}

Values ranged between 0.16 and $0.39 \mathrm{mg} / \mathrm{L}$ the highest value was recorded in May and the lowest was in November.

\subsubsection{Ammonia (mg/L):}

Values ranged between 0.63 and $1.47 \mathrm{mg} / \mathrm{L}$ the highest value was recorded in July and the lowest was in May as shown in table(1)

\subsection{Bio treatment results}

Under standard and steady-state conditions, the bioreactor was very effective when $20 \mathrm{gm}$ of the nano polymer composite granules and 200gm of ceramic particles were added as a substrate for the biofilm formation for each $1 \mathrm{~L}$ of the ground water sample with continuous aeration for 24h. As shown in tables $(2,3,4)$.

\subsection{Identification of bacteria isolates:}

The bacterial species were identified according to vitek2 kit tables mainly Gram negative (Aeromonas sobria, Aeromonas hydrophila, Aeromonas caviae, Enterobacter cloacae, Vibrio cholera, Citrobacter freundii, Actinobacter lwoffii, Klebsiella pneumonia ssp pneumonia,

Pseudomonas aeruginosa) as shown in table 5.

\section{Discussion}

In the present study both the physiochemical and bacteriological characteristics of ground water in Shebin El-kom city were investigated during the period from April to December, 2014. Temperature is a factor of great importance for aquatic ecosystem, as it affects the microorganism as well as physicochemical properties of water (Delince ,1992). temperature decreased by $2.2{ }^{\circ} \mathrm{C}$ and $2.0{ }^{\circ} \mathrm{C}$ in both nano composite bioreactor and ceramic bioreactor respectively. TDS in nano composite decreased from (740 to 654$) \mathrm{mg} / \mathrm{L}$ while in ceramic decreased from (740 to 538) $\mathrm{mg} / \mathrm{L}$. Conductivity in nano composite reduced from (1195 to 1080$) \mu \mathrm{S} / \mathrm{cm}$ while in ceramic decreased from (1195 to 893 ) $\mu \mathrm{S} / \mathrm{cm}$. Turbidity in nano composite increased from (1.6 to 5.1) NTU while in ceramic increased from (1.6 to 2.0) NTU. The elimination of the heavy metals was remarkable in this study as $\mathrm{Fe}$ in nano composite decreased from ( 0.41 to 0.23$) \mathrm{mg} / \mathrm{L}$ while in ceramic decreased from (0.41 to 0.11$) \mathrm{mg} / \mathrm{L}$ and $\mathrm{Mn}$ in nano composite decreased from (1.2 to 0.6$) \mathrm{mg} / \mathrm{L}$ while in ceramic decreased from (1.2 to 0.12$) \mathrm{mg} / \mathrm{L}$. Total hardness in nano composite decreased from (400 to 330) $\mathrm{mg} / \mathrm{L}$ while in ceramic decreased from (400 to 250$) \mathrm{mg} / \mathrm{L}$. Calcium hardness in nano composite decreased from (260 to 220) $\mathrm{mg} / \mathrm{L}$ while in ceramic decreased from (260 to 110) $\mathrm{mg} / \mathrm{L}$. Magnesium hardness in nano composite decreased from (140 to 110$) \mathrm{mg} / \mathrm{L}$ while in ceramic remain constant. Chlorides in nano composite decreased from (105 to 70) $\mathrm{mg} / \mathrm{L}$ while in ceramic decreased from (105 to 90$) \mathrm{mg} / \mathrm{L}$. Sulfate in nano composite increased from (82 to 104) $\mathrm{mg} / \mathrm{L}$ while in ceramic increased from (82 to 120$) \mathrm{mg} / \mathrm{L}$. Phosphate in nano composite decreased from $(0.45$ to $0.34) \mathrm{mg} / \mathrm{L}$ while in ceramic decreased from (0.45 to 0.15$)$ $\mathrm{mg} / \mathrm{L}$. Nitrate in nano composite increased from $(0.27$ to $0.63) \mathrm{mg} / \mathrm{L}$ while in ceramic increased from $(0.27$ to 0.52$)$ $\mathrm{mg} / \mathrm{L}$. Ammonia in nano composite decreased from $(0.8$ to $0.5) \mathrm{mg} / \mathrm{L}$ while in ceramic decreased from (0.8 to 0.55$)$ $\mathrm{mg} / \mathrm{L}$. Ground water is contaminated with coliforms (Total coliform \& Fecal coliform) and pathogenic bacteria. The bacteriological results shows that all the bio treated sample had no pathogenic bacteria (Vibrio cholera, Klebsiella pneumonia, Aeromonas sobria, Aeromonas hydrophila, Aeromonas caviae). The nanocomposite exhibits river sand-like properties, such as higher shear strength in loose and wet forms. These materials have been used to develop an affordable water purifier to deliver clean drinking water at US $\$ 2.5 / y$ per family. The ability to prepare nanostructured compositions at near ambient temperature has wide relevance for adsorption-based water purification (Sankar et al., 2013). The treatment using nanocomposite decreased the concentration of heavy metals. This was due to the nanocomposite used here has a high surface activity that enable it to adsorb organic and inorganic matter 
Table (1) Physicochemical assessment of water sample

\begin{tabular}{|c|c|c|c|c|c|c|c|c|c|}
\hline Parameter & April & May & June & July & August & September & October & November & December \\
\hline Temp ${ }^{\circ} \mathrm{C}$ & 21 & 24 & 24 & 27 & 28 & 26 & 24 & 20 & 18 \\
\hline Turb (NTU) & 1.0 & 1.6 & 1.6 & 0.84 & 0.96 & 0.96 & 1.4 & 1.5 & 1.8 \\
\hline PH & 7.8 & 7.8 & 7.6 & 7.6 & 7.8 & 7.9 & 7.9 & 7.8 & 8.0 \\
\hline TDS (mg/L) & 726 & 724 & 703 & 725 & 722 & 726 & 726 & 714 & 737 \\
\hline Cond $(\mu \mathrm{S} / \mathrm{Cm})$ & 1157 & 1155 & 1118 & 1152 & 1141 & 1156 & 1155 & 1150 & 1175 \\
\hline $\mathrm{Fe}(\mathrm{mg} / \mathrm{L})$ & 0.26 & 0.30 & 0.37 & 0.28 & 0.40 & 0.40 & 0.28 & 0.29 & 0.38 \\
\hline Mn (mg/L) & 1.0 & 1.4 & 1.3 & 1.36 & 1.2 & 1.2 & 1.1 & 1.1 & 1.0 \\
\hline Total . H (mg/L) & 430 & 420 & 400 & 440 & 410 & 440 & 410 & 420 & 450 \\
\hline Calcium . H (mg/L) & 270 & 240 & 250 & 280 & 270 & 260 & 280 & 290 & 270 \\
\hline $\begin{array}{c}\text { Magnesium .H } \\
\text { (mg/L) }\end{array}$ & 160 & 180 & 150 & 160 & 140 & 180 & 130 & 130 & 170 \\
\hline $\mathrm{Ca}^{2+}(\mathrm{mg} / \mathrm{L})$ & 108 & 96 & 100 & 112 & 108 & 104 & 112 & 116 & 108 \\
\hline $\mathrm{Mg}^{2+}(\mathrm{mg} / \mathrm{L})$ & 38 & 43 & 36 & 38 & 34 & 43 & 31 & 31 & 43 \\
\hline Total Alk. (mg/L) & 410 & 390 & 390 & 420 & 400 & 380 & 430 & 416 & 410 \\
\hline Chlorides (mg/L) & 85 & 95 & 100 & 95 & 110 & 95 & 105 & 100 & 120 \\
\hline Sulfate (mg/L) & 57 & 50 & 128 & 144 & 52 & 75 & 88 & 109 & 120 \\
\hline Phosphate (mg/L) & 0.37 & 0.48 & 0.42 & 0.58 & 0.43 & 0.40 & 0.50 & 0.70 & 0.64 \\
\hline Nitrate (mg/L) & 0.24 & 0.39 & 0.32 & 0.25 & 0.29 & 0.26 & 0.27 & 0.16 & 0.29 \\
\hline Ammonia (mg/L) & 1.1 & 0.63 & 0.93 & 1.47 & 1.1 & 1.25 & 1.27 & 1.2 & 0.87 \\
\hline
\end{tabular}


Table (2) The physical measurements of the treated samples.

\begin{tabular}{|c|c|c|c|c|c|}
\hline Parameter & Ground water sample & $\begin{array}{c}\text { After } \\
\text { chlorination }\end{array}$ & nano composite bioreactor & ceramic bioreactor & Max. value \\
\hline Temp ${ }^{\circ} \mathbf{C}$ & 24 & 24 & 22 & 22 & -- \\
\hline Turb (NTU) & 1.6 & 1.55 & 5.1 & 2.0 & 1.0 \\
\hline PH & 8.0 & 7.8 & 8.6 & 5.5 & $6.5-8.5$ \\
\hline TDS $(\mathrm{mg} / \mathrm{L})$ & 740 & 745 & 654 & 838 & 1000 \\
\hline Cond $(\mu \mathrm{S} / \mathrm{Cm})$ & 1195 & 1197 & 1080 & 893 & 1600 \\
\hline
\end{tabular}

Table (3) The chemical measurements of the treated samples.

\begin{tabular}{|c|c|c|c|c|}
\hline Parameter & Ground water sample & $\begin{array}{l}\text { Nano composite } \\
\text { bioreactor }\end{array}$ & Ceramic bioreactor & Max. value \\
\hline $\mathrm{Fe}(\mathrm{mg} / \mathrm{L})$ & 0.41 & 0.23 & 0.11 & 0.3 \\
\hline $\mathrm{Mn}(\mathrm{mg} / \mathrm{L})$ & 1.2 & 0.6 & 0.12 & 0.4 \\
\hline Total . H (mg/L) & 400 & 330 & 250 & 500 \\
\hline Calcium . H (mg/L) & 260 & 220 & 110 & 350 \\
\hline Magnesium .H (mg/L) & 140 & 110 & 140 & 150 \\
\hline $\mathrm{Ca}^{2+}(\mathrm{mg} / \mathrm{L})$ & 104 & 88 & 44 & -- \\
\hline $\mathrm{Mg}^{2+}(\mathrm{mg} / \mathrm{L})$ & 33 & 26 & 33 & -- \\
\hline Total Alk. (mg/L) & 420 & 336 & 220 & 500 \\
\hline Sulfate $(\mathrm{mg} / \mathrm{L})$ & 82 & 104 & 120 & 250 \\
\hline Phosphate (mg/L) & 0.45 & 0.34 & 0.15 & Nil \\
\hline Nitrate (mg/L) & 0.27 & 0.63 & 0.53 & 45 \\
\hline Ammonia (mg/L) & 0.80 & 0.5 & 0.55 & 0.5 \\
\hline
\end{tabular}


Table(4) Bacteriological effects of treatment of ground water sample.

\begin{tabular}{|c|c|c|c|c|}
\hline Parameter & $\begin{array}{c}\text { Ground water } \\
\text { sample }\end{array}$ & $\begin{array}{c}\text { Nano composite } \\
\text { bioreactor }\end{array}$ & $\begin{array}{c}\text { Ceramic } \\
\text { bioreactor }\end{array}$ & $\begin{array}{l}\text { Max. } \\
\text { Value }\end{array}$ \\
\hline $\begin{array}{r}\text { Total Coliform } \\
/ 100 \mathrm{ml}\end{array}$ & 52 & Confluent & Confluent & $<1$ \\
\hline $\begin{array}{r}\text { Fecal Coliform } \\
/ 100 \mathrm{ml}\end{array}$ & 4 & $<1$ & $<1$ & $<1$ \\
\hline $\begin{array}{r}\text { Fecal } \\
\text { Streptococcus } \\
/ 100 \mathrm{ml}\end{array}$ & $<1$ & $<1$ & $<1$ & $<1$ \\
\hline $\begin{array}{r}{ }^{*} \mathrm{HPC} \\
\mathrm{CFU} / \mathrm{ml}\end{array}$ & 233 & 302 & 350 & 50 \\
\hline
\end{tabular}

Table (5) Detection of pathogenic bacteria in different drinking water samples.

\begin{tabular}{|c|c|c|c|}
\hline Organism & Ground water samples & $\begin{array}{c}\text { treated samples with nano } \\
\text { composite }\end{array}$ & $\begin{array}{c}\text { treated samples with } \\
\text { ceramic }\end{array}$ \\
\hline Aeromonas sobria & + & - & - \\
\hline Aeromonas hydrophila & + & - & - \\
\hline Aeromonas caviae & + & - & - \\
\hline Enterobacter cloacae & + & - & - \\
\hline Vibrio cholera & + & - & - \\
\hline Citrobacter freundii & + & - & - \\
\hline Actinobacter Iwoffii & + & + & - \\
\hline Klebsiella pneumonia & + & - & + \\
\hline Pseudomonas aeruginosa & + & + & - \\
\hline
\end{tabular}

dissolved in water besides the adsorption of microorganisms (natural flora) from water. The bioreaction of the microorganisms accumulated on the nanocomposite in the presence of continuous aeration leads to oxidation of the pollutants ( El-Dougdoug et al., 2011). The use of microbial biomass for the biosorption of metals from industrial and municipal wastewater has been proposed as a promising alternative to conventional heavy metal management strategies in past decades. Fungal , bacterial and yeast biomass have been studied with respect to the adsorption of toxic or strategic metals, mainly due to low production costs, rapid sorption and release of metals and reutilization. Accumulation of metals in microbial biomass proceeds by different processes such as uptake by transport, entrapment in extra cellular capsules, precipitation and oxidationreduction reactions. Although the mechanism of metal sorption and uptake by microorganisms is still not completely understood. Sorption to polysaccharides, proteins or other molecules occurring in the outer layer of the cell wall probably plays the most important role(Hisham et al., 2015). Bioremoval of heavy metal from industrial wastes has been demonstrated by several biotechnologies. Various microbial species( Gram positive and Gram negative bacteria) mainly Pseudomonas (Hussein et al., 2004) and Bacillus (Mayers and Beveridge, 1989), have been shown to relatively efficient in the bioaccumulation of copper, zinc, Iron and other metal ions present in polluted effluents. Generally, the cell walls of Gram negative and Gram positive bacteria consists of an anionic matrix of biopolymers such as peptidoglycan, techoic acid, techuronic acid, phospholipids and lip polysaccharide as well as various poly peptides and polysaccharide(Hazaa et al., 2015). The wall polymers enable bacteria to sorbs and bind significant amounts of metals from their surrounding (Mayers and 
Beveridge, 1989). Also no generalizations regarding differences between Gram negative and Gram positive for heavy metals sorption metal removal by one or more process (Mullen et al., 1989).

\section{References}

Abdel-Dayem, S. (1994). Water quality issue in Egypt. Italian-Egyptian Study Days on the Environmental, Cairo 9-20 October, Pp. 81-92

Adler, I. (1987) Proc. Int Eur. Congr. on Biotechnology, Vol. 1,p. 1. Amsterdam, The Netherlands.

AMERICAN SOCIETY FOR TESTING AND MATERIALS. (1982). Standard Methods for Acidity or Alkalinity of Water. Publ. D1067-70 (reapproved 1977), American Soc. Testing and Materials, Philadelphia, Pa.

Atkinson, B. (1975). Biochemical Reactors. Pion Press,London.

Armstrong, F.A.J. (1963). Determination of nitrate in water by ultraviolet spectrophotometry. Anal. Chem. 35:1292.

Batley, G.E. and Gardner, D. (1977). Sampling and storage of natural waters for trace metal analysis. Water Res. 11:745.

Bell, C.R. ; Holder-Franklin, M.A. and Franklin, M. (1980). Heterotrophic bacteria in two Canadian rivers.-I. Seasonal variation in the predominant bacterial populations. Water Res. 14:449.

Betz, J.D. and Noll, C.A. (1950). Total hardness determination by direct colorimetric titration. J. Amer. Water Works Assoc. 42:49.

Caldwell, D.H. and Adams, R.B. (1946). Colorimetric determination of iron in water with ophenanthroline. J. Amer. Water Works Assoc. 38: 727.

Delince, G. (1992): The ecology of the fish pond ecosystem with special reference to Africa. Text book, Kluwer Academic Publishers, 230 Pp.

Dutka, B.D. (1981). Membrane Filtration Applications, Techniques and Problems. Marcel Dekker, Inc., New York, N.Y.

El-Dougdoug, K.A.; Hakim, S. A; Hazaa, M.M.; El-Mansy, K.M. and Sharshar, M.M. ( 2011). Surface water sanitation using bacteriophages and nanocomposite, Egyp. J. Virol, 8: 117-129.

El Tahlawi, M. R.; Farrag A. A. and Ahmed S. S. (2008). Groundwater of Egypt an environmental overview. Environ Geol 55, 639-652.

Evans, T.M. ; Seidler, R.J. and Lechevallier, M.W. (1981). Impact of verification media and resuscitation on accuracy of the membrane filter total coliform enumeration technique. Appl. Environ. Microbiol. 41: 1144.

Facklam, R.R. and Carey, R.B. (1985). Streptococci and aerococci. In E.H. Lennette, A. Ballows, W.J.Hausler, Jr. \& H.J. Shadomy, eds. Manual of Clinical Microbiology, 5th ed. American Soc. Microbiology, Washington, D.C.
Goetz, C.A. and Smith, R.C. (1959). Evaluation of various methods and reagents for total hardness and calcium hardness in water. Iowa State J. Sci. 34:81 (Aug. 15).

Green, B.L. ; Litsky, W. and Sladek, K.J. (1980). Evaluation of membrane filter methods for enumeration of faecal coliforms from marine waters. Mar. Environ. Res. 67:267.

Gross, J.C. ; Houghton, M.P. and Senterfit, L.B. (1975). Presumptive speciation of Streptococcus bovis and other Group D streptococci from human sources by using arginine and pyruvate tests. J. Clin. Microbiol. 1:54.

Hazaa, M. M.; Osman, R. M. A.; Abd ElMen,m, O. M.; Ahmed, A.S. and Mamoun, A. (2015). Studies on the drinking water used in Qalubia and new trend to biotreatment. J. Bas. \& Environ. Sci., 2; 99 109.

Hisham, M. ; Shaaban, M. T. ; Sara, A. ; Fakhrany, M. and Hazaa, M.M. (2015). A new approach in bacteriological and chemical treatment of surface water from drinking purpose. J. Biosci. Appli. Rese., 1(3) 112-120.

Husein, H.; Ibrahim , S. F.; Kandeel, K. and Moawad, H. (2004). Biosorption of heavy metals from wastewater using Pseudomonas Sp. Electronic J. Biotech. ISSN 7,1, 38-46.

Klein, D.A. and WU, S. (1974). Stress: a factor to be considered in heterotrophic microorganism enumeration from aquatic environments. Appl. Microbiol. 37:429.

Lazarova, V. and Manem. J. (1995). Biofilm characterization and activity analysis in water and wastewater treatment, Pergamo Vol. 29. 10,. 22272245.

Madigan, M.T.; Martinko, J.M. and Parker, J. (1997) Brock Biology of Micro organisms, 8th ed. Upper Saddle River, N.J.: Prentice Hall.

Mayer,s I.T. and Beveridge, T.J. (1989). The sorption of metals to Bacillu subtilis walls from dilute solution and simulated Hamilton Harbour water. Cond. J. Microbiol. 35, 8, 764-770.

Means, E.G. ; Hanami, L. ; Ridgway, G.F. and Olson B.H. (1981). Evaluating mediums and plating techniques for enumerating bacteria in water distribution systems. J. Amer. Water Works Assoc. 73: 585 .

Mehlig, R.P. and Hulett, R.H. (1942). Spectrophotometric determination of iron with ophenanthroline and with nitro-o-phenanthroline. Ind. Eng. Chem., Anal. Ed. 14:869.

Mullen, M.D. ; Wolf, D.C. ; Ferris , F.G. ; Beveridge, T.J. ; Flemming, C.A. and Bailey, G.W. (1989). Bacterial sorption of heavy metals. Appl. and Environ. Microbiol . 55, 12, 3143-3149.

Nydahl, F. (1949). Determination of manganese by the persulfate method. Anal. Chem. Acta. 3:144.

Palin, A.T. (1957). The determination of free and combined chlorine in water by the use of diethyl- 
p-phenylene diamin. J. Amer. Water Works, Assoc. 49:873.

Paustian, P. (1987). A novel method to calculate the Mohr chloride titration. In Advances in Water Analysis and Treatment, Proc. 14th Annu. AWWA Water Quality Technology Conf., November 16-20, 1986, Portland, Ore., p. 673. American Water Works Assoc.,Denver, Colo.

Public Health Laboratory Service Water SubCommittee (1953). The effect of sodium thiosulphate on the coliform and Bacterium coli counts of nonchlorinated water samples. J. Hyg. 51:572.

Rossum, J.R. (1975). Checking the accuracy of water analyses through the use of conductivity. $J$. Amer. Water Works Assoc. 67:204.

Rossum, J.R. and Villarruz P. (1961). Suggested methods for turbidimetric determination of sulfate in water. J. Amer. Water Works Assoc. 53: 873.

Sankar, M. U. ; Aigal, S. ; Maliyekkal, S. M. ; Chaudhary, A. ; Anshup, Kumar, A. A. ; Chaudhari, K. and Pradeep, T. (2013). Biopolymer-reinforced synthetic granular nanocomposites for affordable point-of-use water purification, PNAS.110: 8459-8464.
Sartory, D.P. (1980). Membrane filtration faecal coliform determinations with unmodified and modified M-FC medium. Water SA 6:113.

Schwarzenbach, G. and Flaschka, H. (1969). Complexometric Titrations, 2nd ed. Barnes and Nobel, Inc., New York, N.Y.

Shipe, E.L. and Fields, A. (1956). Chelation as a method for maintaining the coliform index in water samples. Pub. Health Rep. 71:974.

Sletten, O. and Bach C.M. (1961). Modified stannous chloride reagent for orthophosphate determination. J. Amer. Water Works Assoc. 53: 1031.

Std method $19^{\text {th }}$ edition.

Subramanian, K.S. ; Chakrabarti, C.L.; Suetlas, J.E. and Maines, I.S. (1978). Preservation of some trace metals in samples of natural waters. Anal. Chem. 50:444.

Subramani, T.; Elango, L. and Damodarasamy ,S. R. (2005). Groundwater quality and its suitability for drinking and agricultural use in Chithar River Basin, Tamil Nadu, India, Environ Geol 47: 10991110. 